\title{
Perkembangan Dan Penerapan Theory Of Acceptance Model (TAM) Di Indonesia
}

\author{
Mainatul Ilmi ${ }^{1}$, Fetri Setyo Liyundira ${ }^{2}$, Afria Rachmawati ${ }^{3}$ \\ Deni Juliasari $^{4}$, Palupi Habsari ${ }^{5}$ \\ Universitas Jember ${ }^{1,2,3,4,5}$
}

\begin{abstract}
The article tells about model of technology acceptance. A system used by the end user necessary to test whether the system effectively and efficiently can be applied by user. Technology Acceptance Model (TAM) adopted the Theory of Reasoned Action (TRA) that is widely used to predict the acceptance and usefulness of the system information. TAM uses a comparison between the Theory of Reasoned Action (TRA) and the Theory of Planned Behavior (TPB). TAM is designed to predict the acceptance or use of information systems by users and profit for a job. An acceptance of the theory of information systems began to be implemented in Indonesia from 2004 until today, which adopts the model proposed Davis et al in 1989. The theory was apparently accepted by the public to assess the acceptance of a system by the user based on its core construct perceived Ease of Use (PEOU) and perceived usefulness (PU). In Indonesia some researchers are implementing TAM 1989 at different locations, in various sectors as well as the time and different situations by using several different methods of analysis in each study. A significant result of variables in TAM lead this theory can be applied further in other information systems in Indonesia in addition to that already done the research for TAM is very easy to apply and be accepted by the public in a variety of sectors, namely in the public sector, business or private.
\end{abstract}

Keywords: Technology Acceptance Model (TAM), perceived Ease of Use, perceived usefulness, system information

\section{Pendahuluan}

Sebuah sistem digunakan oleh pengguna akhir (user) perlu dilakukan pengujian apakah sistem tersebut secara efektif dan efisien dapat diterapkan oleh pengguna. Pengujian yang dilakukan oleh peneliti sistem informasi menggunakan bermacam teori yang dinilai dari susdut pandang masing-masing. Teori yang paling mempengaruhi para peneliti sistem informasi yaitu Theory of Acceptance Model (TAM) yang dikemukakan oleh Davis pada tahun 1986 (Lee, 2003).

Technology Acceptence Model (TAM) mengadopsi Theory of Reasoned 
Action (TRA) yang banyak digunakan untuk memprediksi penerimaan dan kegunaan dari teknologi informasi atau TI (Vankatesh dan Davis, 1996). TAM menggunakan perbandingan antara Theory of Reasoned Action (TRA) dan Theory of Planned Behaviour (TPB). Teori dalam TAM menggambarkan tingkah laku seseorang dengan tujuan penggunaan sistem yang ditentukan dalam dua variabel utama: pertama, perceived usefullness (POU), dimana seseorang percaya bahwa dengan menggunakan sistem dapat meningkatkan kinerja pekerjaannya. Kedua, perceived ease of use (PEOU), dimana seseorang percaya bahwa menggunakan sistem akan memperkecil usaha (Venkatesh dan Davis, 2000).

Dalam 10 tahun setelah diperkenalkannya TAM, penerimaan penguna sistem informasi yang mempertimbangkan penilaian menggunakan TAM berkembang dengan sangat pesat (Venkatesh dan Davis, 2000). Venkatesh dan Davis (2000), hingga Januari tahun 2000 menemukan 424 kutipan jurnal di Social Science Citation Index pada dua artikel jurnal yang memperkenalkan TAM (yaitu Davis, 1989 dan Davis dkk, 1989). Kemudian Lee (2003) menemukan 698 kutipan jurnal di tahun 2003 dimana TAM telah diimplementasikan pada beberapa teknologi yang berbeda (seperti word processors, e-mail, WWW, GSS, Sistem Informasi Rumah Sakit), pada situasi yang berbeda (seperti waktu dan budaya) dengan faktor pengendali yang berbeda (seperti jenis kelamin, tipe dan ukuran organisasi) serta subyek yang berbeda (seperti sarjana, pascasarjana, dan karyawan yang berpengalaman) menerapkan TAM dan mempercayainya memiliki kekuatan yang dapat dimanfaatkan. Hingga saat ini banyak peneliti sistem informasi yang masih melakukan studi menggunakan teori dalam TAM, begitu juga dengan peneliti Indonesia.

Peneliti yang menggunakan TAM di Indonesia banyak dilakukan sejak tahun 2004 hingga saat ini. Kemajuan teknologi dan informasi yang dapat diperoleh dari berbagai media mulai mempengaruhi peneliti untuk mengkaji lebih lanjut penerimaan sistem informasi yang ditawarkan kepada user. Dalam artikel ini peneliti melakukan pengkajian pada 37 artikel yang dipublikasikan dalam jurnaljurnal terakreditasi di Indonesia sejak tahun 2004 - 2015 yang melakukan penelitian tentang TAM. Penelitian ini akan mengulas tentang penelitian TAM untuk 
menjawab rumusan masalah sebagai berikut: (1) Seberapa jauh TAM dikembangkan di Indonesia? (2) Apa yang ditemukan oleh peneliti TAM di Indonesia? (3) Dimana TAM di terapkan?

\section{Pembahasan}

\section{Theory of Reasoned Action (TRA)}

TRA diperkenalkan pada tahun 1975 oleh Fishbein dan Ajzen yang digunakan untuk memprediksi sikap dan tingkah laku individu. Model TRA digtunjukkan dalam gambar 1. TRA menyatakan bahwa penentu utama dari perilaku individu yaitu keinginan untuk berperilaku yang dipengaruhi oleh sikap dalam perilaku dan norma subyektif. Sikap dalam perilaku diartikan sebagai perasaan positif atau negatif seorang individu dalam melaksanakan perilaku tersebut. Sedangkan norma subyektif adalah persepsi seseorang bahwa pemikiran orang-orang disekitarnya tentang apakah ia harus melakukan atau tidak melakukan perilaku tersebut. Sikap dalam perilaku dipengaruhi oleh keyakinan tentang konsekuensi dari tindakan yang dilakukan oleh individu dan aspek keyakinan evaluatif tentang konsekuensi tersebut. Sedangkan norma subyektif dipengaruhi keyakinan normatif tentang yang orang lain harapkan dan motivasi untuk mempengaruhi keyakinan normatif (Hatta, 2009).

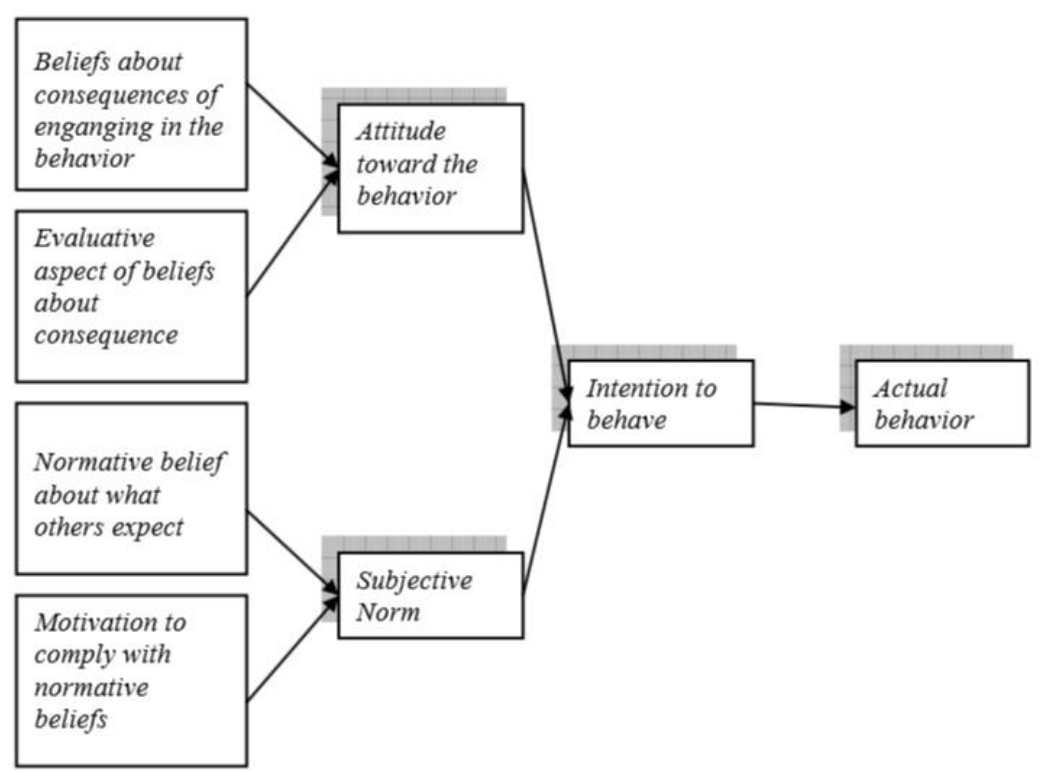

Gambar 1. Alur model dari Theory of Reasoned Action 


\section{Theory of Planned Behavior (TPB)}

TPB merupakan teori yang dikembangkan dari TRA oleh Ajzen pada tahun 1991. Dalam TPB terdapat penambahan variabel persepsi kontrol perilaku untuk menjelaskan situasi ketika individu tidak memiliki kontrol atas perilaku yang diinginkan. Persepsi kontrol perilaku diartikan sebagai persepsi kemudahan atau kesulitan dalam melakukan perilaku (Hatta, 2009). Seperti yang ditunjukkan pada gambar 2, dalam TPB dijelasakan bahwa persepsi kontrol dipengaruhi oleh kontrol keyakinan dan persepsi kekuatan. Kontrol keyakinan adalah keyakinan tentang peluang yang bisa digunakan menjadi pengalaman orang lain atau pengaruh dari informasi lain untuk meningkatkan atau menurunkan kesulitan dalam melakukan perilaku tertentu. Persepsi kekuatan adlah kekuatan dari faktor kontrol yang dapat memfasilitasi atau menghambat pelaksanaan perilaku tertentu.

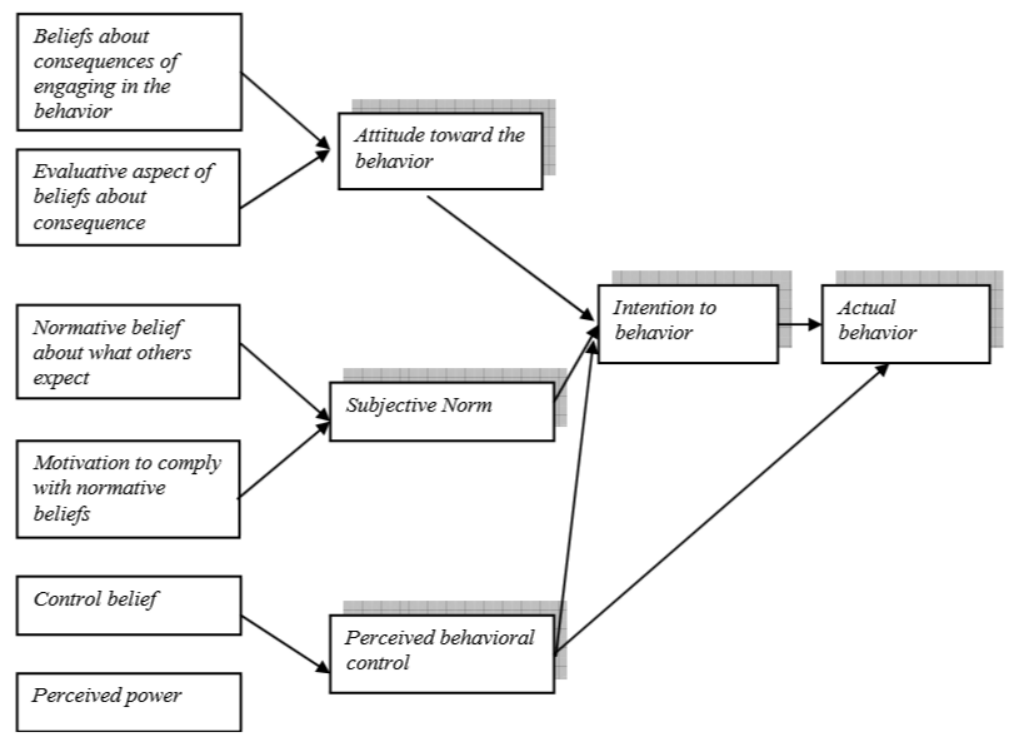

Gambar 2. Alur model dari Theory of Planned Behavior

\section{Technology of Acceptance Model (TAM)}

TAM dikemukakan oleh Davis pada tahun 1989 yang merupakan perpanjangan dari TRA. TAM didesain untuk memprediksi penerimaan atau penggunaan sistem informasi oleh user dan keuntungan bagi sebuah pekerjaan (Hatta, 2009). Penggunaan sebuah teknologi informasi dalam TAM dipengaruhi oleh keinginan untuk berperilaku. Keinginan berperilaku seorang individu 
dipengaruhi oleh dua persepti utama yaitu persepsi manfaat (perceived usefullness/POU) dan persepsi kemudahan dalam menggunakan (perceived ease of use/PEOU). Persepsi manfaat (POU) didefinisikan dimana seseorang percaya bahwa dengan menggunakan sistem dapat meningkatkan kinerja pekerjaannya. Sedangkan, persepsi kemudahan dalam menggunakan (PEOU), dimana seseorang percaya bahwa menggunakan sistem akan memperkecil usaha (Venkatesh dan Davis, 2000).

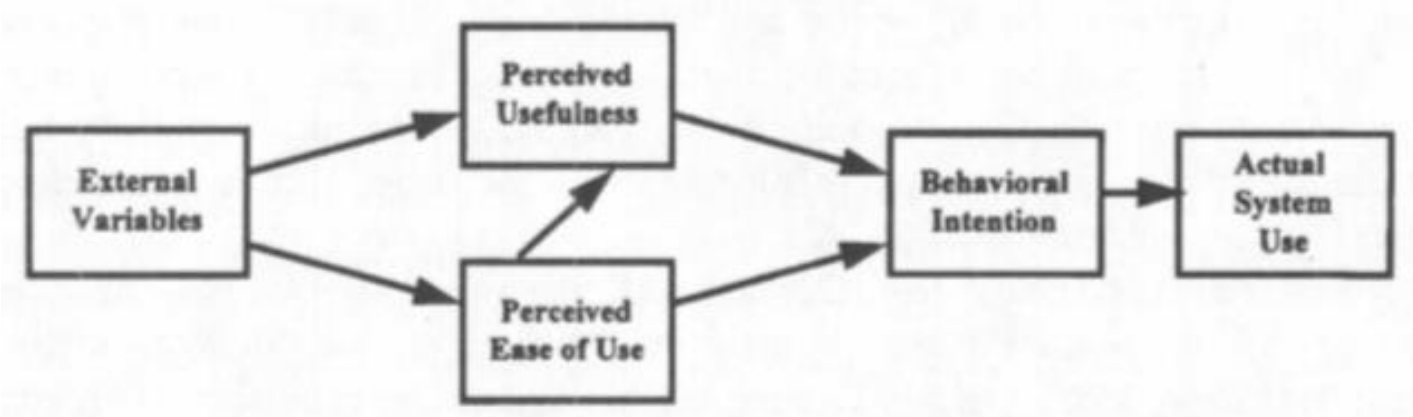

Gambar 3. Technology Acceptence Model (TAM) Davis dan Vankatesh 1996

Pada tahun 2000, Venkatesh dan Davis mengembangkan model TAM yang diberi nama TAM 2 dengan menjelaskan beberapa variabel tambahan yang mempengaruhi variabel perceived usefulness (PU). Seperti yang ditunjukkan dalam Gambar 4, PU dipengaruhi langsung oleh beberapa faktor eksternal seperti norma subyektif, image, kesesuaian pekerjaan, kualitas output dan hasil yang dapat didemonstrasikan. Pengaruh norma subyektif terhadap PU juga dapat terjadi melalui variabel image atau pengalaman dari individu. Kemudian juga terdapat dua variabel yang mempengaruh keinginan untuk menggunakan yaitu variabel pengalaman dan voluntaries yang keduanya sebagai variabel moderating dari variabel norma subyektif.

Pengaruh norma subyektif konsisten dengan model TRA yang berati persepsi sesorang bahwa orang-orang penting baginya berpikir dia harus atau tidak harus melakukan perilaku tertentu. Norma subyektif dapat mempengaruhi keinginan seseorang dalam berperilaku secara langsung. Keinginan tersebut dapat dicapai dengan voluntaries atau karena adanya aturan yang mengharuskan seseorang untuk menggunakan sebuah teknologi informasi. Dalam TAM 2, variabel 
voluntaries menjadi variabel moderasi antara variabel norma subyektif yang mempengaruhi keinginian individu untuk berperilaku. Pengaruh langsung dari norma subyektif juga dapat dimoderasi oleh pengalaman seorang individu dalam menggunakan teknologi informasi. PU dapat secara langsung dipengaruhi oleh norma subyektif dan dipengaruhi norma subyektif melalui image. Image juga dapat mempengaruhi PU secara langsung. Image diartikan sebagai keyakinan seseorang yang berada dalam kelompok sosial dalam dunia kerja bahwa dia melakukan perilaku dalam penggunaan sistem kemudian cenderung dapat mengangkatnya tetap berdiri dalam kelompok.

PU juga dipengaruhi langsung oleh kesesuaian pekerjaan, kualitas output dan hasil yang dapat dapat didemonstrasikan. Kesesuaian pekerjaaan diartikan sebagai persepsi individu mengenai sejauh mana sistem target ini berlaku untuk pekerjaannya. Kemudian kualitas output didefinisikan sebagai capaian dari sebuah sistem dengan pertimbangan seberapa baik sistem melakukan tugas-tugas dalam pekerjaan seseorang. Sedangkan hasil yang dapat didemonstrasikan berarti perwujudan dari hasil mengguakan sistem (Venkatesh dan Davis, 2000).

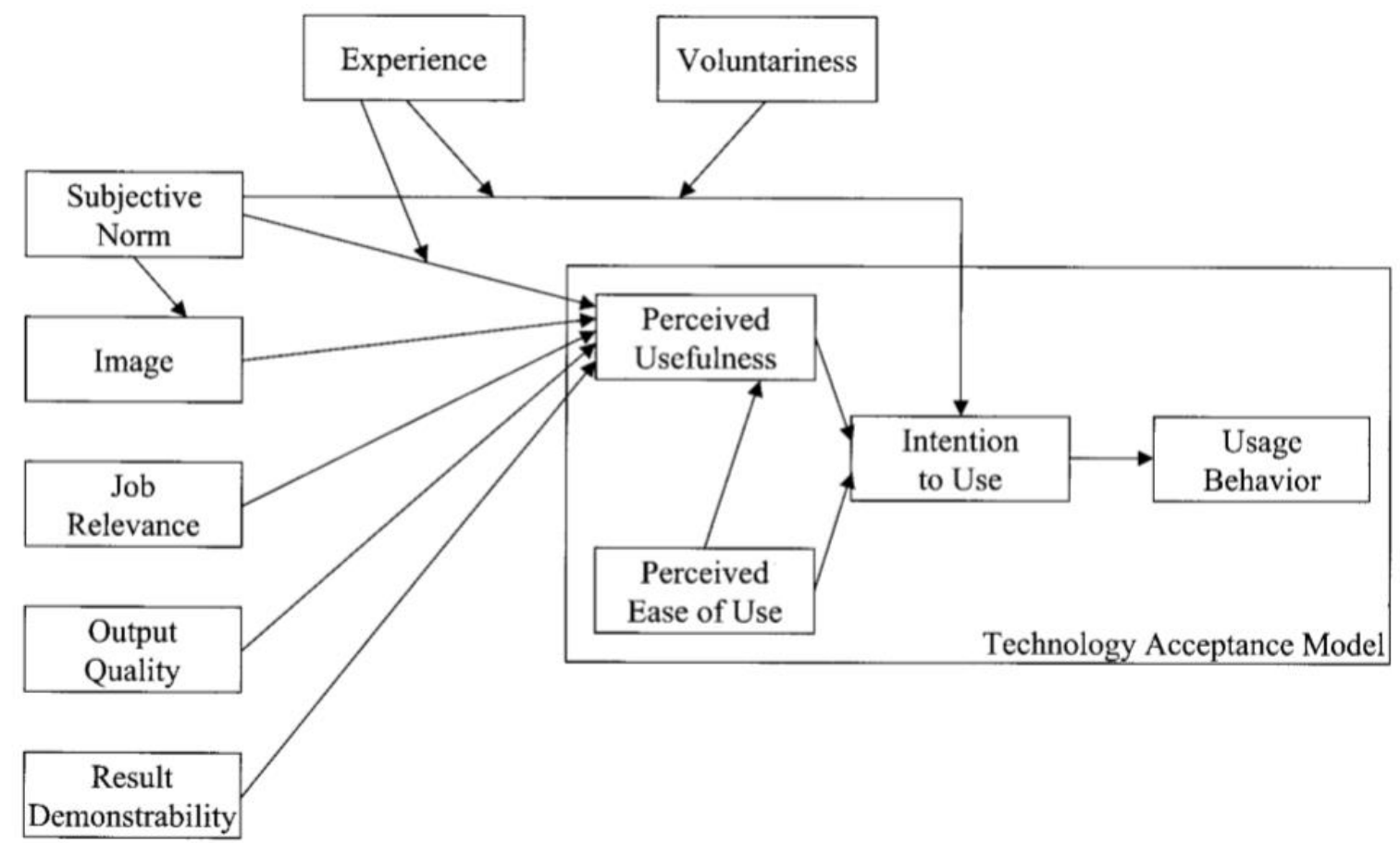

Gambar 4. Alur TAM 2. Pengembangan dari Technology Acceptance Model 
Pada tahun 2008, Venkathesh dan Bala kembali mengembangkan TAM yang diberi nama TAM 3 (Gambar 5). TAM 3 terdiri dari faktor-faktor yang mempengaruhi PU dan PEOU secara terpisah. PU dipengaruhi oleh variabel proses sosial (norma subyektif, voluntaries, pengalaman dan image) dan variabel proses berperan kognitif (kesesuaian pekerjaan, kualitas output dan hasil yang dapat didemonstrasikan). PEOU dipengaruhi oleh variabel penahan (computer selefficacy, persepsi kontrol eksternal, kecemasan komputer, computer playfullness) dan variabel penyesuaian (persepsi kenyamanan dan dapat digunakan secara obyektif).

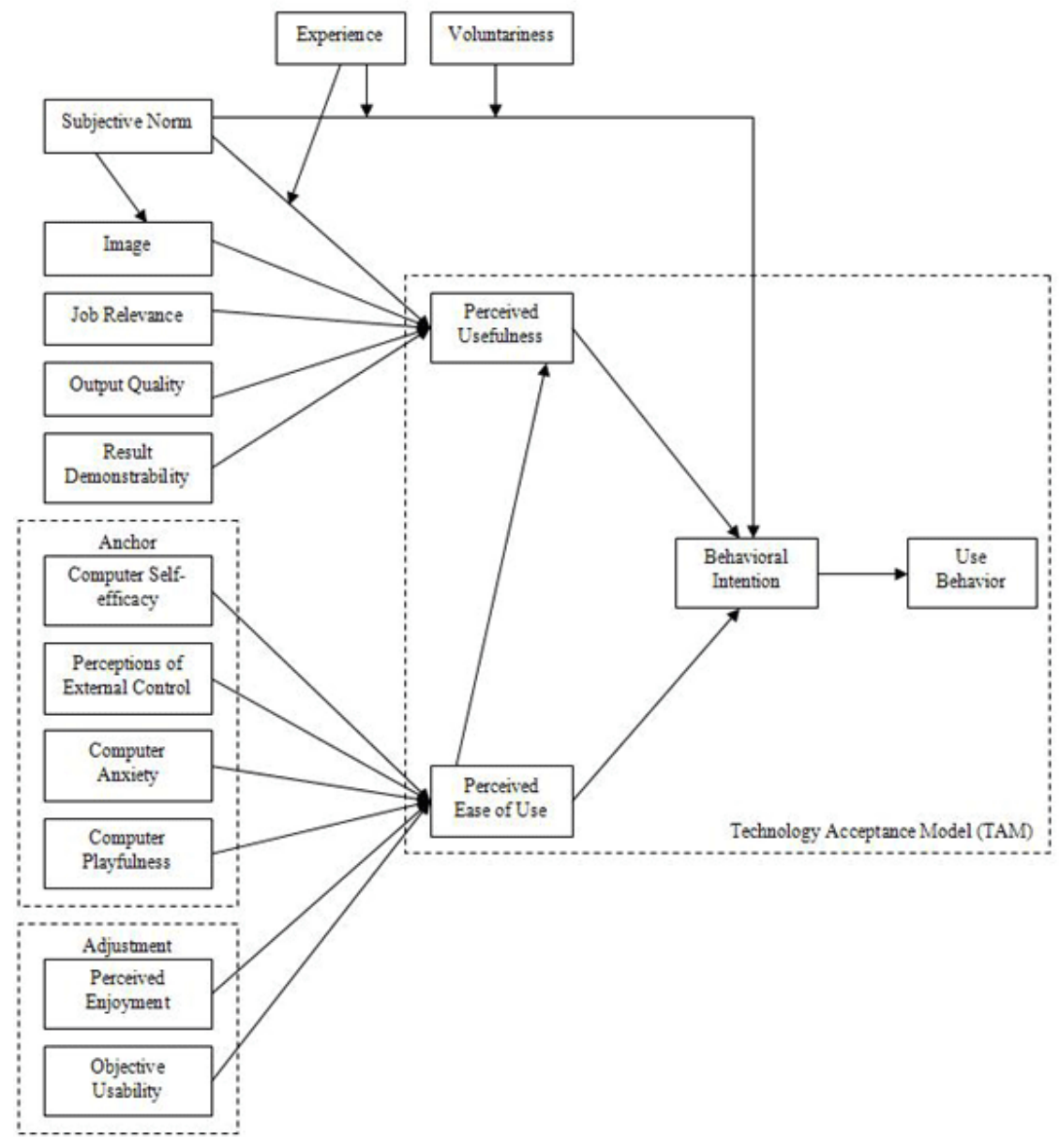

Gambar 5. TAM 3, Venkatesh dan Bala (2008)

\section{Penelitian TAM Di Indonesia}

Ada banyak penelitian di Indonesia yang menerapkan TAM model Davis yang dikemukakan pada tahun 1989. Artikel ini memberikan beberapa contoh 
penelitian yang dilakukan di Indonesia dengan menggunakan TAM sebagai dasar teori dalam penelitian yang dilakukan di beberapa sektor dari tahun ke tahun. Misalnya, pada tahun 2004 terdapat 2 penelitian di bidang pemerintahan yang menggunakan PC yakni persepsi pengguna tentang kegunaan Teknik Audit Berbantuan Komputer/TABK (PU) tetap terbukti memiliki pengaruh terhadap penerimaan pengguna akan TABK. Penerapan pada tahun 2011 salah satunya diambil penelitian di bidang perbankan bahwa persepsi kemudahan penggunaan (EOU) berpengaruh signifikan terhadap persepsi manfaat (USE) dan sikap (ATT). Dilanjutkan penelitian penerapan TAM pada tahun 2012 dalam penggunaan aplikasi pajak. Penerapan TAM di tahun 2013 semakin merata di bidang sektor publik dalam aplikasi SIMDA yakni Persepsi sikap penggunaan aplikasi SIMDA berpengaruh terhadap perilaku untuk tetap menggunakan Aplikasi SIMDA yang diimplementasikan di SKPD Kabupaten Pasaman.

Pada tahun 2014 penerapan TAM sudah masuk dalam bidang pariwisata, pelaku bisnis, pelajar, dan kearsipan dan perusahaan. Terdapat beberapa penelitian yang dapat dicontohkan sehingga dapat disimpulkan bahwa persepsi manfaat dan kemudahan penggunaan adalah faktor utama dalam menerapkan. Hingga pada tahun 2015 penelitian penerapan TAM sudah menjadi sebuah kebutuhan dalam bidang pendidikan yaitu penelitian ini memberi respon yang baik dalam penggunaan aplikasi media pembelajaran e-learning berbasis multiplatform, Aplikasi dapat beroperasi pada 3 operating system yaitu Windows, Android, dan Ubuntu.

Lee (2003) membagi sistem informasi dalam beberapa tipe yaitu sistem bisnis, sistem tujuan umum, sistem kantor dan sistem komunikasi. Kategori sistem bisnis yaitu Computerized Model, Case Tools, Hospital IS (Telemedicine), DSS, GSS, GDSS, Experts support System. Kategori sistem tujuan umum yaitu Windows, PC (or Microcomputer), WWW (or e-commerce), Computer Resource Center. Kategori sistem kantor yaitu Word processor, Spreadsheet, Presentation S/W, Database program. Kategori sistem komunikasi yaitu E-mail, V-mail, FAX, Dial-up Systems.

Dari beberapa penelitian yang sudah dijelaskan diatas, penerapan TAM dari 
tahun ke tahun di Indonesia dapat dilihat dalam grafik dibawah ini :

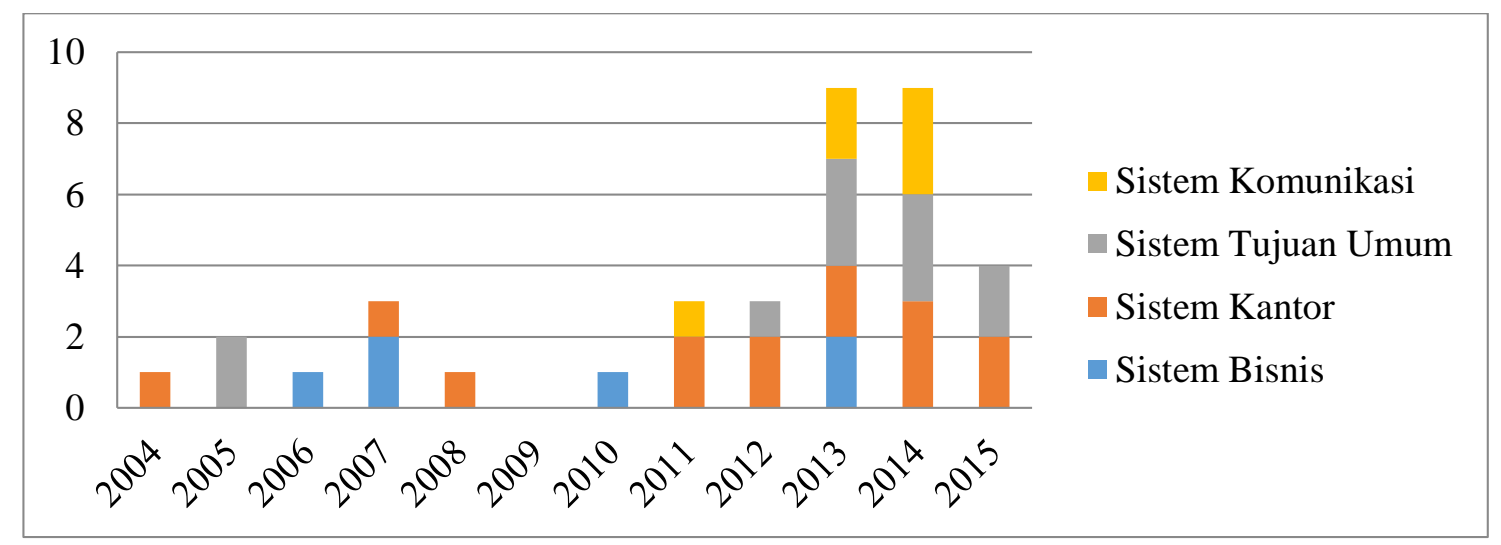

Gambar 6. Fokus Penelitian TAM di Indonesia

Penelitian Natalia Tangke tahun 2004 berfokus pada analisa Penerimaan Penerapan Teknik Audit Berbantuan Komputer (TABK) dengan Menggunakan Technology Acceptance Model (TAM) yang dilaksanakan pada sistem yang digunakan di kantor sektor publik. Hasil penelitian menunjukkan bahwa persepsi pengguna tentang kemudahan menggunakan TABK (PEOU) memiliki pengaruh yang signifikan terhadap persepsi pengguna tentang penggunaan TABK (PU) dan sikap pengguna tentang penggunaan TABK (ATT), dan tidak terbukti memiliki efek yang signifikan terhadap sikap pengguna tentang penggunaan TABK (ATT). Sikap pengguna tentang penggunaan TABK (ATT) tidak terbukti berpengaruh signifikan terhadap penerimaan pengguna pada TABK.

Penelitian lain pada sistem kantor di sektor publik dapat dilihat dari hasil penelitian Rahardi (2007) tentang peranan teknologi informasi dalam peningkatan pelayanan di sektor publik dengan mengadopsi model TAM menunjukkan model TAM memiliki kemudahan penggunaan dan manfaat yang dirasakan tidak berpengaruh terhadap penerimaan teknlogi dan informasi yang diterapkan di kantor sektor publikk, sebaliknya kemudahan penggunaan teknologi informasi berpengaruh terhadap manfaat yang dirasakan.

Penelitian di tahun 2005 yang menerapkan model TAM dengan objek 
pengguna internet dapat ditemukan dalam penelitian Sulistyarini (2005) yang menguji collaboration technology berdasarkan pada teori TAM dengan objek penelitiannya adalah penerapan internet content filters dalam browser internet yang dipergunakan user untuk melakukan browsing di internet. Hasil penelitian menunjukkan bahwa karakteristik pekerjaan berpengaruh dominan terhadap penerapan collaboration technology.

Wahid (2005) juga melakukan penelitian dengan memahami internet di Indonesia dengan menggunakan TAM yang dikembangkan oleh Davis et al. dengan memasukkan variabel eksternalnya adalah gender. Pengaruh kemudahan yang dipersepsikan terhadap adopsi lebih tinggi dikalangan perempuan dari pada pegaruhnya di kalangan laki-laki. Tingkat keterampilan teknologi informasi (selfefficacy) rendah di kalangan wanita. Faktor sosial dan budaya (seperti bagaimana posisi yang diberikan kepada wanita di masyarakat) juga mempengaruhi dalam konteks adopsi teknologi.

Studi Sekundera (2006) menguji model penerimaan untuk penggunaan sistem core banking di Bank ABC menggunakan model Teknologi. TAM diterapkan untuk menguji sistem bisnis berbasis online di perbankan. Hasil penelitian menunjukkan bahwa pengujian sistem dengan model TAM dapat menjelaskan faktor-faktor yang mempengaruhi penerimaan penggunaan sistem core banking di Bank ABC, yaitu variabel usability dan kemudahan penggunaan. Sedangkan penggunaan model EUCS, ketepatan waktu dan kemudahan dapat mempengaruhi penerimaan penggunaan sistem core banking di Bank ABC, namun variabel isi dan bentuk tidak mempengaruhi penerimaan penggunaan sistem core banking di Bank ABC.

Dalam dunia bisnis, sektor perbankan menuntut untuk selalu diadakannya inovasi-inovasi dalam rangka pengembangan teknologi di dalamnya, seperti penelitian yang dilakukan oleh Maharsi (2007) dan Kusuma (2007) yang meneliti tentang layanan internet banking dalam perbankan. Maharsi (2007) memperleh bukti bahwa faktor yang mempengaruhi minat menggunakan internet banking adalah Perceived Usefulness, Perceived Ease of Use, dan Perceived Credibility. Faktor lain, seperti faktor Computer Self Efficacy juga memberikan pengaruh pada 
minat menggunakan internet banking secara tidak langsung melalui Perceived Ease of Use, Perceived Usefulness, dan Perceived Credibility. Sedangkan dalam Kusuma (2007) disampaikan bahwa jasa aliansi, kesesuaian tugas, dan persepsi kemudahan penggunaan merupakan faktor-faktor penting yang mendorong sikap positif terhadap pengadopsian jasa pelayanan internet banking. Pengguna dari budaya yang berbeda menggambarkan perbedaan kepentingan dalam menilai teknologi.

Yananto (2008) melakukan penelitian pada sistem yang diterapkan di koperasi. Penelitian tersebut bertujuan untuk menganalisis implikasi pengunaan TIK pada Koperasi, Usaha Kecil dan Menengah (KUKM) peserta UG-ICTA dengan pendekatan Technology Acceptance Model (TAM). Hasil penelitian menyatakan bahwa persepsi pengguna terhadap kemudahan dalam menggunakan perangkat TIK (PEOU) berpengaruh secara signifikan terhadap persepsi pengguna terhadap tingkat kegunaan perangkat TIK $(P U)$. Persepsi pengguna tentang penggunaan TIK (PU) dan sikap pengguna terhadap penggunaan TIK (ATU) secara signifikan mempengaruhi nilai strategis kebijakan perusahaan (SV), sedangkan persepsi pengguna tentang kemudahan penggunaan TIK (PEOU) tidak secara signifikan mempengaruhi nilai strategis kebijakan perusahaan (SV). Besarnya pengaruh penggunaan TIK pada peningkatan daya saing KUKM dapat dilihat dari nilai strategis yang diperoleh perusahaan (SV).

Sudaryana (2010) melakukan penelitian untuk mengetahui faktor - faktor yang mempengaruhi penerimaan perusahaan pengguna jasa terhadap penerapan sistem online Indonesia National Single Window (INSW), dengan menggunakan Technology Acceptance Model (TAM). Variabel yang diteliti yakni persepsi pengguna tentang kemudahan penggunaan sistem INSW (PEOU), persepsi pengguna tentang kemudahan penggunaan system INSW (PU), sikap pengguna efisiensi proses sistem INSW (EP), dan penerimaan pengguna terhadap sistem INSW (ACC). Penelitian ini berhasil membuktikan bahwa faktor yang berpengaruh langsung terhadap efisiensi proses (EP) pengguna jasa adalah persepsi perusahaan pengguna aplikasi INSW tentang penerimaan sistem INSW (ACC). Persepsi Perusahaan pengguna aplikasi INSW terhadap kemudahan dalam menggunakan aplikasi INSW (PEOU) dan persepsi perusahaan pengguna aplikasi INSW tentang 
kegunaan aplikasi INSW (PU) juga berpengaruh terhadap Process Efficiency (EP) perusahaan, hanya saja pengaruhnya tidak langsung tetapi melalui persepsi perusahaan pengguna sistem INSW tentang penerimaan aplikasi INSW (ACC).

Penelitian yang dilakukan oleh Mayasari (2011) terhadap sistem berbasis online di perbankan pada pengguna Klik BCA. Penelitian ini menunjukkan bahwa persepsi kemudahan penggunaan memiliki pengaruh terhadap persepsi manfaat dan sikap nasabah dalam menggunakan internet banking. Persepsi manfaat tidak berpengaruh terhadap sikap dan intensi perilaku nasabah dalam menggunakan internet banking.

Adapun penelitian pada KAP di daerah Jawa Tengah yang dilakukan oleh Dewayanto (2011) yang menyimpulkan bahwa kemudahan penggunaan komputer mikro akan mengurangi usaha (baik waktu maupun tenaga) seseorang (auditor) di dalam melaksanakan aktivitas audit.

Penelitian lain dilakukan oleh Asrori (2011) menilai penggunaan dosen terhadap Sistem Informasi Penilaian Kinerja (Silkados) yang bertujuan untuk meningkatkam laporan akuntabilitas beban kerja dan penilaian kinerja dosen di Universitas Negeri Semarang meyimpulkan bahwa Silkados memberikan manfaat dan mudah digunakan dosen sebagai pemakai sebagai sarana evaluasi beban kerja dan kinerja. Kegunaan dan kemudahan penggunaan Silkados berpengaruh pada intensi menggunakan Silkados. Kemudian, intensi dalam penggunaan Silkados berpengaruh pada penggunaan Silkados untuk tujuan meningkatkan akuntabilitas pelaporan beban kerja dan evaluasi kinerja dosen sebagai bagian dari perwujudan Tridharma Perguruan Tinggi.

Penelitian dilakukan oleh Suwardikha (2012) dan Hillery (2012) di sektor perbankan yang mempengaruhi penggunaan SIA yang menyatakan bahwa persepsi manfaat dari penggunaan TIK adalah faktor kunci UMKM dalam menerapkan TIK, serta penerapan TIK lebih banyak pada UMKM di Qingdao (Provinsi Sandong Cina Utara) dibandingkan dengan Depok. Di kalangan pelajar juga diteliti dalam penggunaan TAM yakni pada penelitian yang dilakukan oleh Ana (2012) menyatakan bahwa Technology Acceptance Model (TAM) dapat digunakan untuk membangun model penerimaan teknologi internet di kalangan pelajar. 
Ananggadipa (2012) melakukan penelitian dalam penggunaan aplikasi pajak yang menunjukkan bahwa persepsi kontrol keperilakuan merupakan faktor utama yang mempengaruhi perilaku wajib pajak dalam menggunakan Aplikasi Pajak. Theory of Planned Behavior (TPB) dan Technology Acceptance Model (TAM) dapat diintegrasikan sebagai model penelitian untuk menjelaskan perilaku wajib pajak dalam menggunakan Aplikasi Pajak.

Pertiwi (2013) melakukan penelitian pada Bank Mandiri, dalam penelitian ini menunjukkan bahwa risiko, manfaat dan kemudahaan penggunaan sangat mempengaruhi kepercayaan nasabah dalam menggunakan internet banking. Penelitian selanjutnya dilakukan oleh Brian Dwi (2013) yang menunjukkan bahwa terdapat pengaruh positif dan signifikan pada persepsi kemudahan penggunaan terhadap minat menggunakan internet banking

Ari (2013) yang melakukan penelitian di sektor perbankan juga menyimpulkan dari h asil penelitiannya bahwa konstruk kegunaan persepsian dan kemudahan penggunaan persepsian dalam Technology Acceptance Model berpengaruh positif terhadap sikap perilaku dalam menggunakan Core Banking System. Konstruk sikap perilaku dalam Technology Acceptance Model dan konstruk pengaruh sosial yang merupakan pengembangan dari Technology Acceptance Model berpengaruh positif terhadap minat menggunakan Core Banking System.

Penelitian yang dilakukan oleh Muhammad (2013) membuktikan bahwa persepsi kemudahan penggunaan berpengaruh signifikan dan positif terhadap persepsi kemanfaatan. Persepsi kemudahan penggunaan berpengaruh signifikan dan positif terhadap sikap penggunaan. Persepsi kemanfaatan berpengaruh signifikan positif terhadap sikap penggunaan. Persepsi kemanfaatan berpengaruh signifikan positif terhadap perilaku untuk tetap menggunakan. Sikap penggunaan berpengaruh signifikan positif terhadap perilaku untuk tetap menggunakan. Perilaku untuk tetap menggunakan berpengaruh signifikan positif terhadap keberhasilan implementasi aplikasi SIKD.

Selanjutnya Azriani (2013) melakukan penelitian yang menunjukkan bahwa minat keperilakuan individu menggunakan piranti lunak dipengaruhi oleh persepsi 
kemudahan, sikap, dan kontrol perilaku individu. Sedangkan, persepsi kegunaan dan norma subjektif tidak memengaruhi minat keperilakuan individu. Penelitiaan oleh Fuad Budiman (2013) yang meneliti aplikasi SIMDA dapat diterapkan dengan baik dengan memakai factor-faktor TAM didalamnya. Keberhasilan aplikasi SIMDA memberikan manfaat positif bagi pengguna.

TAM juga dapat diterapkan di lingkungan pelajar yaitu penelitian yang dilakukan oleh Saifudin (2013) memperlihatkan bahwa kemampuan individu (computer self-efficacy and knowledge of search domain) berpengaruh terhadap ketertarikan mahasiswa dalam menggunakan internet jika dilihat dari kemudahan dalam penggunaannya. Kemudian, norma subyektif mempengaruhi ketertarikan mahasiswa secara langsung walaupun kegunaan ataupun kemudahan dalam penggunaannya tidak diperhatikan.

Selanjutnya penelitian Satya (2013) yang menganalisis konsep kerangka kerja kebijakan internet yang sehat dalam konteks penelitian ini menganalisis semua bentuk tingkat kepentingan dalam enggunakan internet di lingkungan perguruan tinggi yang digunakan dengan benar, sebagai analisis dalam menentukan atau bagaimana mengatur itu, menerapkannya, dan mengelolanya secara efektif dan efisien, sehingga tujuan optimasi kinerja dapat dicapai.

Slamet Erma Yudi, Johan J.C. Tambotoh (2013) dan Destiana (2013) menyatakan teknologi informasi dan media sosial akan dapat dengan cepat diterima oleh lingkup sosial apabila memiliki karateristik berupa tingkat penggunaan yang mudah, memberi manfaat dan memberi nilai tambah bagi individu maupun organisasi.

Pada pelaku bisnis, TAM juga bisa diterapkan bahwa sebagian besar pengusaha muda di kota Bandung telah merasakan manfaat dari smartphone dalam mendukung aktivitas bisnisnya, kemudian smartphone juga memiliki desain yang sangat user friendly sehingga memudahkan para penggunanya. Penelitian ini dilakukan Firdaus (2013). Selanjutnya Penelitian Taasim (2013) mendapati tahap penerimaan dalam e-pembayaran adalah tinggi namun penerimaan dalam menggantikannya sebagai counter maya berada pada tahap yang minimum. Dapatan ini penting sebagai pengurusan kewangan pengguna dengan lebih 
sistematik dan seterusnya mampu menjadikan pengguna yang bijak dalam pengurusan keuangan.

Penelitian Agustini et al. (2014) menggunakan 4 (empat) konstruksi yang telah dimodifikasi dari model penelitian TAM sebelumnya yaitu: Persepsi kemudahan penggunaan Persepsi tentang kemudahan penggunaan (Perceived Ease Of Use), persepsi terhadap kemanfaatan (Perceived Usefulness), sikap penggunaan (Attitude Toward Using), dan perilaku untuk tetap menggunakan (Behavioral Intention To Use). Hasil penelitian menunjukkan bahwa penerapan sistem panduan wisata berbasis mobile yang terintegrasi dapat menjalankan fungsi-fungsi yang diperlukan dalam mencari info tentang kawasan wisata di Kabupaten Buleleng secara rinci, bersama dengan fasilitas umum terdekat. Dari hasil pengujian hipotesis, ditemukan bahwa persepsi manfaat dan kemudahan penggunaan merupakan faktor utama dalam menerapkan sistem panduan wisata berbasis mobile yang terintegrasi dan respons pelaku wisata terhadap sistem tersebut positif.

Penelitian yang dilakukan oleh Ni Luh Nyoman Sherina Devi dan I Wayan Suartana (2014) dengan judul artikel analisis Technology Acceptance Model (TAM) tentang penggunaan sistem informasi di Nusa Dua Beach Hotel \& Spa menyimpulkan bahwa variabel computer self-efficacy dan variabel kepercayaan memiliki pengaruh positif dan signifikan terhadap kedua variabel dependen (persepsi manfaat dan persepsi kemudahan penggunaan). Berbeda halnya dengan variabel personalization yang tidak mempengaruhi kedua variabel, karena responden berada dalam lingkup pekerjaan yang kompleks dan diharuskan untuk menyelesaikan pekerjaan dalam waktu yang terbatas.

Penelitian Rizal (2014) tentang “Analisis Penerapan Project Management Information System (PMIS) Menggunakan Metode Technolog Acceptance Model (TAM) Studi Kasus PT. INDOSAT, Tbk". Hasil dari penelitian ini adalah variabel laten Perceived Easy of Use (PEOU) berpengaruh pada variabel Perceived Usefulness (PU). Indikator yang mempengaruhi variable laten PU dapat menjelaskan bahwa dengan adanya PMIS dapat memudahkan pekerjaan serta meningkatkan produktivitas. Variabel Usefulness (PU) berpengaruh kepada variabel Intention to use (ITU). Sehingga dapat disimpulkan niat untuk 
menggunakan PMIS dipengaruhi oleh kegunaan dari PMIS tersebut dan manfaat PMIS itu timbul diakibatkan oleh mudahnya pengoperasian sistem tersebut.

Penelitian yang dilakukan tahun 2014 oleh Aldioctavia Vicka Paramita dan Mudjahidin menganalisis kemanfaatan dan kemudahan penggunaan aplikasi manajemen surat dengan pendekatan Technology Acceptance Model pada PT. XYZ Surabaya yang bergerak dibidang kelistrikan di area Jawa Timur. Berdasarkan hasil pegujian, persepsi sikap terhadap persepsi minat tidak berpengaruh secara signifikan. Persepsi kemudahan berpengaruh secara positif terhadap persepsi kemanfaatan. Persepsi kemanfaatan dan kemudahan juga berpengaruh secara positif terhadap persepsi sikap. Hal yang sama juga terjadi pada pengaruh persepsi minat terhadap kenyataan. Hasil penelitian ini memverifikasi bahwa persepsi kemudahan penggunaan berpengaruh terhadap persepsi kemanfaatan penggunaan layanan AMS.

Penelitian Titus Kristanto (2015) tentang “Rancang Bangun Aplikasi ELearning Berbasis Multiplatform untuk Mata Pelajaran Bahasa Indonesia dengan Menggunakan Pendekatan Technology Acceptance Model (TAM)”. Hasil dari penelitian ini adalah: 1) Siswa cukup baik dalam respon terhadap penggunaan aplikasi media pembelajaran e-learning berbasis multiplatform. 2) aplikasi layak untuk digunakan dan diterapkan. 3) Aplikasi dapat beroperasi pada 3 operating system yaitu Windows, Android, dan Ubuntu.

Penelitian yang dilakukan oleh Hangono Arie (2015) bertujuan untuk menjelaskan pengaruh masing-masing variabel TAM model Davis 1996 terhadap kondisi nyata penggunan sistem jejaring sosial instagram. Dari hasil analisis path yang mereka gunakan dalam penelitian telah menhasilkan kesimpulan bahwa variabel peresepsi Kemudahan Penggunaan (Perceived Ease Of Use) berpengaruh terhadap Persepsi Kemanfaatan (Perceived Usefulness), variabel peresepsi kemudahan penggunaan (perceive ease of use) memiliki pengaruh terhadap Sikap Penggunaan (Attitude Toward Using), variabel persepsi kemanfaatan (perceived usefulness) memiliki pengaruh terhadap Sikap Penggunaan (Attitude Toward Using), variabel Sikap Penggunaan (Attitude Toward Using) memiliki pengaruh signifikan positif terhadap perilaku untuk menggunakan (behavioral intention use), 
variabel perilaku untuk mengggunakan (behavioral intention use) memiliki pengaruh signifikan positif terhadap kondisi nyata penggunaan sistem (actual system usage).

Penelitian yang dilakukan oleh Dedi Rianto Rahadi dan Zanial (2015) menjelaskan bahwa penelitian ini tujuannya adalah untuk mengetahui pengaruh persepsi manfaat yang dirasakan (PU) dan dirasakan kemudahan penggunaan (PEU) dari sikap (ATU) dalam menerima teknologi informasi (ATI) di perbankan. Dari hasil penelitiannya telah menunjukkan persepsi variabel kemudahan penggunaan (PEU) berpengaruh positif dan signifikan pada sikap menggunakan IT (ATU). persepsi variabel manfaat yang dirasakan (PU) adalah efek positif tetapi tidak signifikan pada sikap menggunakan IT (ATU). persepsi variabel mudah digunakan (PEU) positif dan signifikan berdampak pada variabel persepsi manfaat yang dirasakan (PU). Variabel sikap menggunakan IT (ATU) berpengaruh positif dan signifikan pada penerimaan TI (ATI).

Penelitian yang dilakukan oleh Endang Fatmawati (2015) dirancang untuk mendukung Technology Acceptance Model (TAM) diperkenalkan oleh Davis pada tahun 1986. Dari hasil penelitannya dapat disimpulkan bahwa Model TAM dalam menganalisis penerimaan sistem informasi di perpustakaan adalah untuk mengetahui sikap penerimaan pengguna terhadap suatu teknologi. Menganalisis penerimaan sistem informasi di sebuah perpustakaan dilihat dari persepsi kemudahan penggunaan dan kebermanfaatan menggunakan model TAM dapat mengetahui sikap penerimaan pengguna baik itu pustakawan maupun pemustaka terhadap sistem informasi perpustakaan.

Penelitian di Indonesia yang menggunakan pengujian penerimaan sistem TI oleh user dengan menerapkan TAM dapat dikategorikan dalam beberapa tipe yaitu pada sistem bisnis, sistem bertujuan umum, sistem kantor dan sistem komunikasi sesuai dengan penggolongan yang disampaikan oleh Lee (2003). Sedangkan sektor yang menerapakan model dalam TAM yakni pada sektor perbankan, sektor publik, pendidikan, perkantoran, perhotelan hingga pariwisata. Berikut ini disajikan ringkasan dari penelitian di indonesia yang menerapkan model TAM serta sistem informasi yang digunakan dalam TAM. 


\section{Kesimpulan}

Sebuah teori penerimaan sistem informasi mulai diterapkan di Indonesia sejak tahun 2004 yang mengadopsi model yang dikemukakan davis et al tahun 1989. Teori tersebut rupanya diterima oleh masyarakat untuk menilai penerimaan sebuah sistem oleh pengguna berdasarkan konstruk utamanya yaitu PEOU dan PU. Di indonesia sendiri beberapa peneliti lebih banyak yang menerapkan model tersebut pada lokasi yang berbeda serta waktu dan situasi yang berbeda. Hasil yang signifikan terhadap variabel-variabel dalam TAM mengakibatkan teori ini dapat diterapkan lebih lanjut pada sistem informasi lain di Indonesia selain yang sudah dilakukan penelitian.

\section{DAFTAR PUSTAKA}

Agustini. Ketut, dkk. Penerapan Sistem Terintegrasi Panduan Pariwisata Berbasis Mobile Untuk Pelaku Pariwisata Di Kabupaten Buleleng Dengan Model TAM. ISSN: 2303-3142 Vol. 3, No. 1, April 2014.

Ana, I Made Agus. 2012. Pengembangan Model Penerimaan Teknologi Internet Oleh Pelajar Dengan Menggunakan Konsep Technology Acceptance Model (Tam) Jurnal Sistem Informasi Mti-Ui, Volume 4, Nomor 2

Angganadipa, Septian, Studi Empiris Pada Penggunaan Aplikasi Pajak : Integrasi Theory Of Planned Behavior Dan Technology Acceptance Model (Studi Empiris Pada Perusahaan Go Public Di Indonesia) Universitas Diponegoro Semarang. 2012

Asrori. 2011. Penggunaan Sistem Informasi Penilaian Kinerja Dosen Dan Akuntabilitas Kinerja Dosen. Jdm Vol. 2, No. 2, 2011, Pp: 162-168. Jurnal Dinamika Manajemen

Azriani, Narulita Rahmi. 2013. Minat Keperilakuan Individu Menggunakan Piranti Lunak Sebagai Penunjang Pelaporan Keuangan Jurnal Akuntansi Multiparadigma. Jamal Volume 4 Nomor 3 Halaman 330-507 Malang, Desember 2013

Destiani, Ika. 2013. Penerimaan Media Sosial: Kajian Dalam Kalangan Pelajar Universiti Di Palembang Jurnal Komunikasi Malaysian Journal Of 
Communication Jilid 29(2) 2013: 125-140

Dewayanto, Totok. Analisis Penerimaan Komputer Mikro Dengan Menggunakan

Technology Acceptance Model (Tam) Pada Kantor Akuntan Publik (Kap)

Di Jawa Tengah. Jurnal Stie Semarang, Vol 3, No 2, Edisi Juni 2011

Erma Yudi, Slamet. 2013.Analisis Pemanfaatan Teknologi Informasi Menggunakan Pendekatan Innovation And Diffusion Theory (Idt) Dan

Technology Acceptance Model (Tam) Seminar Nasional Ke 8 Tahun 2013

: Rekayasa Teknologi Industri Dan Informasi

Fatmawati, Endang. 2015. Technology Acceptance Model (Tam) Untuk Menganalisis Penerimaan Terhadap Sistem Informasi Perpustakaan. Dalam Jurnal Iqra' Volume 09 No.01 Mei, 2015.

Firdaus, Oktri Muhammad. 2013. Efektivitas Penggunaan Smart Phone Dalamendukung Kegiatan Bisnis Pengusaha Muda Di Kota Bandung Menggunakan Technology Acceptance Model (Tam) Seminar Nasional Ienaco - 2013 Issn: 2337-4349

Grace. Potoh. 2013. Analisis Persepsi Pemanfaatan Sistem Informasi Komandan Sikd Pada Provinsi Dan Kabupaten/Kota Di Sulawesi Jurnal Bppk, Volume 6 Nomor 1, 2013, Halaman 1-14

Hangono, Ari, Aditya, Siti Ragil Handayani dan Heru susilo. 2015. Analisis Praktek TAM (Technology Acceptance Model) Dalam Mendukug Bisnis Online Dengan Memanfaatkan Jejaring Sosial Instagram. Fakultas Ilmu Administrasi Universitas Brawijaya. Dalam Jurnal Administrasi Bisnis (JAB)|Vol. 26 No. 1September2015

Hatta, Atika J., Model Of Information System Operation Based On Technology Acceptance Model For Micro Financial Institutions. Journal of Economics, Business and Accountancy Ventura Volume 14, No. 3, December 2011, pages $251-268$

Hillery, Deboner. 2012. Penerapan Teknologi Informasi Dan Komunikasi (Tik) Pada Umkm Dengan Menggunakan 1,2,3 Technology Acceptance Model (Tam) (Studi Kasus Di Depok Dan Qingdao) Prosiding Seminar Ilmiah Nasional Komputer Dan Sistem Intelijen (Kommit 2012) Vol. 7 September 
2012. Universitas Gunadarma - Depok 18 - 19 September 2012

Kristanto, Titus. Rinci Kembang Hapsari. Vinda Setia Nita. Siti Maimunah.

Rancang Bangun Aplikasi E-Learning Berbasis Multiplatform untuk Mata

Pelajaran Bahasa Indonesia dengan Menggunakan Pendekatan Tehnology

Acceptance Model (TAM). Jurnal Teknik Informatika dan Sistem Informasi

Volume 1 Nomor 3 Desember 2015

Kusuma, Hadri. Dwi Susilowati. "Determinan Pengadopsian Layanan Internet

Banking: Perspektif Konsumen Perbankan Daerah Istimewa Yogyakarta”.

JAAI Volume 11 No. 2, Desember 2007: 125-139.

Lee, Younghwa, dkk. The Technology Acceptance Model: Past, Present, and

Future. Communications of the Association for Information Systems

(Volume 12, Article 50) 2003:752-780

Maharsi, Sri. Yuliani Mulyadi. "Faktor-faktor yang Mempengaruhi Minat Nasabah

Menggunakan Internet Banking dengan Menggunakan Kerangka Technology

Acceptance Model (TAM)”. Jurnal Akuntansi dan Keuangan, Vol. 9, No. 1,

Mei 2007: 18-28.

Mayasari. Feronica, dkk. "Anteseden Dan Konsekuen Sikap Nasabah Dalam

Menggunakan Internet Banking Dengan Menggunakan Kerangka

Technology Acceptance Model (Tam) (Survey Pada Pengguna Klikbca)”.

Seminar Nasional Teknologi Informasi \& Komunikasi Terapan 2011

(Semantik 2011).

Muhammad, Satria, 2013. Pengaruh Persepsi Kemudahan Penggunaan Terhadap

Keberhasilan Implementasi Aplikasi Sistem Informasi Keuangan Daerah

(Sikd) Dengan Persepsi Kemanfaatan, Sikap Pengguna Dan Perilaku Untuk

Tetap Menggunakan Sebagai Variabel Intervening Fakultas Ekonomi Universitas Negeri Padang Jl. Prof. Dr. Hamka Kampus Air Tawar Padang.

Nyoman Sherina, Ni Luh. Suartana, I Wayan. Analisis Technology Acceptance

Model (Tam) Terhadap Penggunaan Sistem Informasi Di Nusa Dua Beach

Hotel \& Spa. E-Jurnal Akuntansi Universitas Udayana 6.1 (2014):167-184

Pertiwi, Fita. 2013. Pengaruh Risiko, Manfaat Dan Kemudahan Penggunaan

Terhadap Kepercayaan Nasabah Dalam Menggunakan Internet Banking Di 
Yogyakarta (Studi Kasus Pada Nasabah Bank Mandiri) Universitas Pgri Yogyakarta, Jl. Pgri I No. 117 Sonosewu, Yogyakarta.

Putri Sekti, Dessanti. 2013. Pengaruh Technology Acceptance Model Dan Pengembangannya Dalam Perilaku Menggunakan Core Banking System Jurnal Keuangan Dan Perbankan, Vol.17, No.2 Mei 2013

Rahardi, Dr. Dedi Rianto. "Peranan Teknologi Informasi Dalam Peningkatan Pelayanan di Sektor Publik". Seminar Nasional Teknologi 2007 (SNT 2007). Yogyakarta, 24 November 2007.

Rizal, A. “Analisis Penerapan Project Management Information System (PMIS) Menggunakan Metode Technology Acceptance Model (TAM) Studi Kasus PT. INDOSAT, Tbk”. Income Tech, Jurnal Telekomunikasi dan Komputer, Vol. 5, No. 1, Januari 2014.

Saifudin, Santi Ayu Nindyowati Anita Damajanti. Pengaruh Kualitas Informasi, Kemampuan Individual, dan Norma Subyektif Terhadap Minat Mahasiswa Akuntansi dalam Menggunakan Internet Sebagai Media Sumber Pustaka (Studi Empiris di Undip dan Unika Soegijapranata Semarang). Jurnal Dinamika Akuntansi Vol. 5, No. 1, Maret 2013, pp. 21-34

Satya, Barka. 2013. Analisis Penerimaan (Acceptance) Penerapan Internet Sehat Dengan Technology Acceptance Model (Tam) (Studi Kasus Pada Stmik Amikom Yogyakarta) Jurnal Dasi Issn: 1411-3201 Vol. 14 No. 1 Maret 2013 Sekundera, P. L. Charlesto. “Analisis Penerimaan Pengguna Akhir Dengan Menggunakan Technology Acceptance Model Dan End User Computing Satisfaction Terhadap Penerapan Sistem Core Banking Pada Bank ABC”. Tesis. Universitas Diponegoro. 2006.

Suardikha, I Made Shada. 2012. Pengaruh Implementasi Budaya Tri Hita Karana Terhadap Penggunaan Sistem Informasi Akuntansi Dimediasi KeyakinanDiri Atas Komputer, Keinovatifan Personal, Persepsi Kegunaan, Dan Persepsi Kemudahan Penggunaan Pada Bank Perkreditan Rakyat Di Bali. Sna 15 Banjarmasin Universitas Lambung Mangkurat 20-23 Sept 2012 Sudaryana, Hendra, Sonny dan Fajar Baskoro. 'Indonesia National Single Window Menggunakan Technology Acceptance Model Studi Kasus Balai Karantina 
Ikan.” Prosiding Seminar Nasional Manajemen Teknologi XII.Program Studi MMT-ITS, Surabaya 7 Agustus 2010.

Sulistyarini, Dhanik. Baroroh Lestari. "Pengaruh Karakteristik Teknologi dan

Karakteristik Pekerjaan Terhadap Penerpan Collaboration Technology Internet Content Filter". Mediator, Vol. 6 No. 2, Desember 2005.

Taasim, Shairil Izwan. 2013. Penerimaan Pengguna Terhadap Kaedah Pembayaran Elektronik (Consumer's Acceptance Towards Electronic Payment Method) Jurnal Ekonomi Malaysia 47(1) 2013 - 12

Tangke, Natalia. "Analisa Penerimaan Penerapan Teknik Audit Berbantuan Komputer (TABK) Dengan Menggunakan Technology Acceptance Model (TAM) Pada Badan Pemeriksa Keuangan (BPK) RI”. Jurnal Akuntansi \& Keuangan Vol. 6, No. 1, Mei 2004: 10- 28.

Vankatesh, Viswanath dan Davis. 1996. A model of the Antecedents of Perceived Ease of Use: Development and Test. Decision Sciences. Vol. 27 No. 3. Pg. 451

Vankatesh, Viswanath dan Davis. 2000. A model of the Antecedents of Perceived Ease of Use: Development and Test. Management Science. Vol. 46 No. 2. Pp. $186-204$

Vicka Paramita, Aldioctavia. Analisis Kemanfaatan Dan Kemudahan Penggunaan Aplikasi Manajemen Surat Dengan Pendekatan Technology Acceptance Model Pada Pt. Xyz Surabaya. Jurnal Teknik Pomits Vol. 3, No. 2, (2014)

Wahid, Fathul. "Apakah Perempuan Indonesia Terbelakang dalam Adopsi Internet?: Temuan Empiris”. Teknoin, Vol. 10, No. 3, September 2005, 209 224.

Yananto dan Dharma Tintri Ediraras. “Analisis Technology Acceptance Model (Tam) Terhadap Implikasi Pemanfaatan TIK Pada KUKM Di Indonesia (Studi Empiris Pada Kukm Peserta Ug-Icta 2008). Jurnal Ekonomi Bisnis No. 2 Vol. 13, Agustus 2008.

Yudiastuti, Helda. Siti Saudah. Irwansyah. "Penerapan Model TAM Dalam Analisa Pemanfaatan Schoolnet (Jardiknas Zona Sekolah) Oleh Pelajar SMP di Kota Palembang”. Seminar Nasional Teknologi Informasi dan Multimedia 2014. 
Relasi : Jurnal Ekonomi, Vol. 16, No. 2, Juli 2020, hlm. 436-458

STMIK Amikom Yogyakarta, 8 Februari 2014.

Zainal, Dedi Rianto Rahadi. 2015. Anlisis Technology Acceptance Model Pada Industri Perbankan. Program Pasca Sarjana. Dalam Jurnal Sistem Informasi (JSI), VOL. 7, NO. 2, Oktober 2015 